\title{
Polish Vocational Competence Standards for the Needs of Adult Continuing Education and the European Labour Market
}

\author{
Dagmara Kowalik \\ Kazimierz Pulaski University of Technology and Humanities of Radom, Poland
}

\begin{abstract}
The article presents the research on the development of Polish vocational competence standards. The author pays attention to the possibility of the use of standards for the needs of adult continuing education. After the consideration of the European and national qualification frameworks, the standards can be used as a tool for the design of vocational qualification courses. The designed programmes will contribute to the vocational mobility of employees, the flexibility of the educational offers and they will strengthen the European labour market.
\end{abstract}

Index Terms - vocational training, vocational competence standard, adult continuing education, European Qualification Framework

\section{Introduction}

In the vocational education process, a learner continuously acquires new knowledge, skills and social competences. The result of such a process includes the educational outcomes, knowledge, skills and social competences. These elements create the vocational qualifications, which can be acquired through the formal, the non-formal and the informal education. In some European countries the vocational qualifications are comparable [1]. The priority is the recognition of vocational qualifications of the employees from the European countries on the international labour market. The formal achievements of qualifications should be confirmed by the appropriate institution.

In order to ensure greater clarity, comparability and recognition of qualifications in Europe, common flexible European Qualification Framework was developed (EQF). In the European Union countries the National Qualification Framework are obligatory (NQF) [2]. Vocational qualifications acquired by learners and vocational training can contribute to the international mobility [3].

The vocational education system should be compatible with globalisation trends and scientific and technical changes. Therefore, the research on the labour market are used to identify the vocational competences, which are needed on the market. The results of the research allow for the development of a vocational competence standard. [4]. The competences indicated by the employers aim at supporting how to design vocational education training [5]. The education based on this assumption fulfils the needs of the labour market. The adjustment of the competences from the standard to the appropriate $\mathrm{EQF}$ and $\mathrm{NQF}$ levels [6] indicates the appropriate level of the educational outcomes and the additional characteristics of the Polish Qualification Framework. Such a way allows for the detailed description of the beneficiaries of the course. The methodology of the development of vocational competence standards enlarge the elaborations developed before [7]. The aim of the activities is to implement the Polish society into the continuing education. The courses developed on the competence standards are the part of the lifelong education.

\section{Modernisation of the Polish Vocational Education}

In order to adjust the Polish education to the European directions, new basic curricula and educational programmes for school professions have been developed. The management and pedagogical staff of schools and institutions of vocational education was prepared for the implementation of solutions coming from the modernisation of vocational education [8]. The next step was to improve and to disseminate the cooperation between vocational schools and employers [9]. The documents developed consider the qualifications expected by the employers from the graduates of vocational schools [10]. Table 1 presents the qualifications for selected professions from the construction area, possible to obtain in the schools system.

TABLE I Qualifications for selected professions from the construction area possible to obtain in the school system [10]

\begin{tabular}{|c|c|c|c|c|}
\hline \multicolumn{2}{|c|}{ Qualification } & \multicolumn{3}{|c|}{ Profession } \\
\hline No & $\begin{array}{c}\text { Name according to the } \\
\text { construction sector }\end{array}$ & $\begin{array}{c}\text { Construction } \\
\text { fitter }\end{array}$ & Plasterer & $\begin{array}{c}\text { Construction } \\
\text { Technician }\end{array}$ \\
\hline Q1 & $\begin{array}{c}\text { Assembly of } \\
\text { constructions }\end{array}$ & $\mathrm{x}$ & $\mathrm{x}$ & $\mathrm{x}$ \\
\hline Q2 & $\begin{array}{c}\text { Organisation and control } \\
\text { of construction works } \\
\text { works }\end{array}$ & $\begin{array}{c}\text { Design of estimates and } \\
\text { preparation of tender } \\
\text { documentation }\end{array}$ & & $\mathrm{x}$ \\
\hline Q3 & & $\mathrm{x}$ \\
\hline
\end{tabular}

After the obtainment of the Q1 qualification and its confirmation during the exam, a graduate gains the possibility to work as a qualified worker in the professions Constructions Fitter or Plasterer. In further education it is possible to obtain Q2 and Q3 qualifications. The confirmation and the obtainment of the certificate gives the possibility of the 
obtainment of the technician title and to work in the Construction Technician profession.

The significant element of the Polish vocational education is the development of the support system for vocational schools using the modular curricula [11].

For out-of-school education the implementation of a new methodology of vocational competence standards has a great significance [12]. During the developmental process of standards the analysis of national vocational competences required by the employers was conducted.

\section{Characteristic Elements of the Vocational Competence Standard}

The Polish competence standard describes the profession considering vocational competences necessary to undertake vocational activities on a specific workstation. The competences are defined as all what is understood, known and done by the worker and what is adequate for the situation in the workplace. The competences are described as knowledge, skills and social competences [12]. Competences have to be accepted by the representatives of the professional and branch organisations, employers and other key social partners.

The research was done with the use of the activity analysis method [13]. The questionnaire was a research tool. Below, the author presents the research results of the development of the standard for the profession Construction Manager. The research questionnaire was developed by the factual experts, including people from the profession area and the methodological experts. The research included some stages. One of them comprised of pilot research, which aimed at the verification of the research sample. After the introduction of eventual changes, main research was done. The standard developed by the experts was evaluated and reviewed by the evaluators, reviewers and the branch committee.

\subsection{Research}

The pilot research was performed in 2 companies on 6 workstations. The respondents did not propose important comments regarding the proposed descriptions in the questionnaire. The research confirmed the factual correctness of the questionnaire. The main research included 7 companies and 16 workstations. The selection of the companies ensured the diversity of activities form, the size of the company and the localisation in Poland.

\subsection{Characteristics of the research sample}

According to the accepted methodology, the research sample included people working on the workstations typical for the tested profession. Table 2 presents the characteristic of the workstation considered in the research.
TABLE II Characteristics of the workstations for the profession Construction Manager [10]

\begin{tabular}{|c|c|c|}
\hline No & Characteristics & People \% \\
\hline \multicolumn{3}{|c|}{ Sex } \\
\hline 1. & Women & 12,5 \\
\hline 2. & Men & 87,5 \\
\hline \multicolumn{2}{|l|}{ Total } & 100 \\
\hline \multicolumn{3}{|c|}{ Size of the company } \\
\hline 1. & Big & 20 \\
\hline 2. & Middle & 60 \\
\hline 3. & Small & 20 \\
\hline \multicolumn{2}{|l|}{ Total } & 100 \\
\hline \multicolumn{3}{|c|}{ Kind of economic activity of a company } \\
\hline 1. & Production & 25 \\
\hline 2. & Services & 37.5 \\
\hline 3. & Production \& Services & 37,5 \\
\hline \multicolumn{2}{|l|}{ Total } & 100 \\
\hline \multicolumn{3}{|c|}{ Age } \\
\hline 1. & $18-25$ & 13 \\
\hline 2. & $26-40$ & 56 \\
\hline 3. & 41 and more & 31 \\
\hline \multicolumn{2}{|l|}{ Total } & 100 \\
\hline \multicolumn{3}{|c|}{ Education } \\
\hline 1. & Secondary & 13 \\
\hline 2. & Engineer & 13 \\
\hline 3. & Master & 74 \\
\hline \multicolumn{2}{|l|}{ Total } & 100 \\
\hline \multicolumn{3}{|c|}{ Actual workstation } \\
\hline 1. & Manager & 74 \\
\hline 2. & Project manager & 6 \\
\hline 3. & Director & 20 \\
\hline \multicolumn{2}{|l|}{ Total } & 100 \\
\hline
\end{tabular}

\subsection{Characteristic elements of the description of the vocational competence standards for the Construction Manager profession}

In the international and the Polish Classification of Professions Specialties each profession has a special code [14]. The Construction Manager 132301 belongs to the group 1323 Construction Managers [15]. According to the NQF, this profession is relevant for the $6^{\text {th }}$ level of general characteristic. Table 3 includes the most relevant competences for the employers in the Construction Manager profession. 
TABLE III Vocational competences described in the competence standard for the Construction Manager profession

\begin{tabular}{|c|c|c|}
\hline No & Vocational competences & $\begin{array}{c}\text { Reference to } \\
\text { vocational tasks }\end{array}$ \\
\hline Kz1. & $\begin{array}{l}\text { Supervision and coordination of } \\
\text { construction works }\end{array}$ & $\begin{array}{l}\mathrm{Z} 1, \mathrm{Z} 2, \mathrm{Z} 4, \mathrm{Z} 5, \mathrm{Z6}, \\
\mathrm{Z7}, \mathrm{Z} 11\end{array}$ \\
\hline Kz2. & $\begin{array}{l}\text { Elaboration, current verification and } \\
\text { design of the construction documentation }\end{array}$ & $\begin{array}{l}\text { Z1, Z3, Z6, Z7, Z8, } \\
\text { Z9, Z10 }\end{array}$ \\
\hline Kz3. & $\begin{array}{l}\text { Cooperation with the investor, organs of } \\
\text { the construction supervision and other } \\
\text { organ of the public administration }\end{array}$ & $\begin{array}{l}\mathrm{Z1}, \mathrm{Z} 2, \mathrm{Z4}, \mathrm{Z9} \\
\mathrm{Z10}, \mathrm{Z} 11\end{array}$ \\
\hline $\mathrm{KzS}$ & Social competences & $\mathrm{Z} 1 \div \mathrm{Z} 11$ \\
\hline
\end{tabular}

Table 4 includes the vocational tasks indicated in the standard, performed on the workstation by the Construction Manager. The tasks are correlated with the vocational competences.

TABLE IV Vocational tasks indicated in the competence standard for the Construction Manager profession

\begin{tabular}{|c|l|l|}
\hline No & \multicolumn{1}{|c|}{ Vocational tasks } & $\begin{array}{l}\text { Reference to } \\
\text { competences }\end{array}$ \\
\hline Z1. & $\begin{array}{l}\text { To organise the own and team work considering } \\
\text { industrial safety rules, fire protection, } \\
\text { environment protection and the calculation of } \\
\text { people, equipment and financial and materials } \\
\text { schedule }\end{array}$ & $\begin{array}{l}\mathrm{Kz} 1, \mathrm{Kz} 2, \\
\mathrm{Kz} 3, \mathrm{KzS}\end{array}$ \\
\hline Z2. & To take over and to protect the construction area & $\mathrm{Kz} 1, \mathrm{Kz} 3, \mathrm{KzS}$ \\
\hline Z3. & To conduct the construction documentation & $\mathrm{Kz2,} \mathrm{KzS}$ \\
\hline Z4. & $\begin{array}{l}\text { To plan and to coordinate the construction area } \\
\text { according to the construction permission }\end{array}$ & $\mathrm{Kz} 1, \mathrm{Kz} 3, \mathrm{KzS}$ \\
\hline Z5. & $\begin{array}{l}\text { To coordinate the activities protecting from the } \\
\text { industrial safety threats and ensuring health } \\
\text { protection }\end{array}$ & $\mathrm{Kz} 1, \mathrm{KzS}$ \\
\hline Z6. & $\begin{array}{l}\text { To stop the construction works in the case of any } \\
\text { threats }\end{array}$ & $\mathrm{Kz} 1, \mathrm{Kz} 2, \mathrm{KzS}$ \\
\hline Z7. & $\begin{array}{l}\text { To realise the recommendations indicated in the } \\
\text { construction documentation }\end{array}$ & $\mathrm{Kz} 1, \mathrm{Kz} 2, \mathrm{KzS}$ \\
\hline Z8. & To report the acceptance of vanishing works & $\mathrm{Kz2,} \mathrm{KzS}$ \\
\hline Z9. & To prepare the executive documentation & $\mathrm{Kz2,Kz3,} \mathrm{KzS}$ \\
\hline Z10. & To report the construction object for acceptance & $\mathrm{Kz} 2, \mathrm{Kz} 3, \mathrm{KzS}$ \\
\hline Z11. & $\begin{array}{l}\text { To participate in acceptance activities and to } \\
\text { ensure the elimination of eventual faults }\end{array}$ & $\mathrm{Kz} 1, \mathrm{Kz} 3, \mathrm{KzS}$ \\
\hline
\end{tabular}

\section{Relations between the Vocational Competence Standard and the EQF and the NQF}

After having considered the general characteristics of the Polish Qualification Framework, the competences necessary for undertaking activities in the Construction Manager profession were referred to the qualifications at the $6^{\text {th }}$ level of the $\mathrm{EQF}$ and the NQF. It is adequate with the education of the $1^{\text {st }}$ level.

A worker undertaking the Construction Manager profession has the following competences:

- knowledge: knows facts, theories, methods and complex dependencies between them, different conditions of the economic activity within the construction at the advanced level.

- skills: is able to undertake activities in an innovative way and to solve complex and non typical problems in changing and not predictable conditions, to plan his own lifelong learning, to communicate in the society and to justify his own opinion.

The performance of all vocational tasks identified in the standard requires the social competences, which are relevant with the NQF descriptors:

- to disseminate appropriate attitudes in the economic activity,

- to make decisions regarding the accordance of the works finished with the rules of the construction law,

- to take responsibility for the results of his own activities and decisions,

- to assess critically his own and team vocational activities.

The employers indicated the gaps in competences, which are called as key competences. A key competence is understood as the combination of skills, knowledge and attitudes adequate to situations. The key competences are needed for the self-realisation and self-development. They support to be an active citizen and to employed [16]. The assessment of the importance of key competences for the Construction Manager profession is presented in Figure 1.

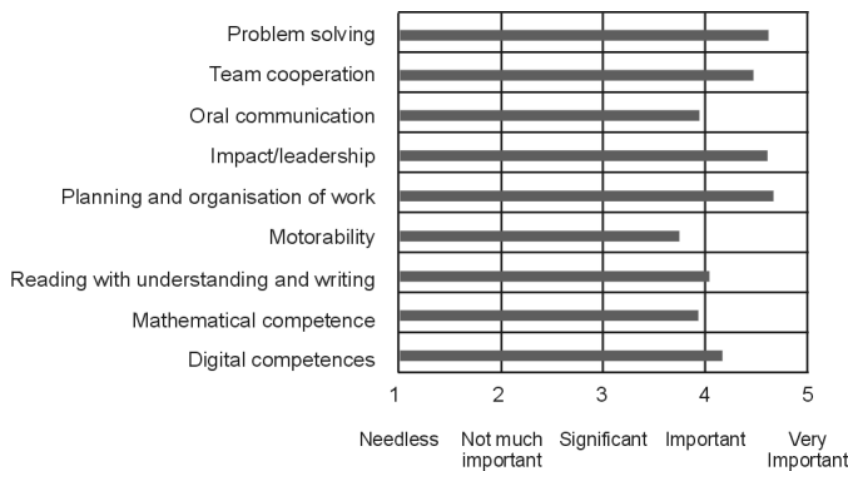

Figure 1 Key competences for the Construction Manager profession.

The employers indicated the most important key competences for the Construction Manager profession: planning and organisation of work, impact / leadership and problem solving.

\section{Conclusions}

The presented research results indicates the actual needs of the employers / labour market for competences in professions from construction areas. They show significance of vocational education. A graduate of vocational education, who gained Q1 qualification in the Construction fitter or Plasterer professions can continue further education in technical secondary school without the necessity of learning of the Q1 qualification once again. The next stage of education is to complete Q2 and Q3 qualifications in the Construction Technician profession. The analogue completion of qualifications can concern other stages of education. The 
condition of the continuation of education at the university is the A exam passed at secondary school.

The vocational competences identified in the standard for the Construction Manager profession are correlated with actual vocational tasks. It guarantees to complete competences expected by the employers. Table 1 comprises of set of qualifications, which can be achieved in formal education. Table 3 identifies competences, which are needed to undertake the Construction Manager profession. A learner will be able to gather the outcomes as vocational competences. After their validation they will be treated as vocational competences.

Polish vocational competence standards aim at the increase of the flexibility and the access of adults to lifelong learning. The standards can be used for the description of qualifications, which will be the part of the National Repository of Qualifications. The acquisition of vocational competences by learners, which are currently required will contribute to the vocational mobility of people on the European labour market.

\section{References}

[1] J. J.W. Powell, H. Solga, "Analyzing the nexus of higher education and vocational training in Europe: a comparative-institutional framework", Studies in Higher Education, vol. 35, issue 6, pp. 705-721, 2010.

[2] Declaration of the European Ministers of Vocational Education and Training, and the European Commission, convened in Copenhagen, 2002 ,

[3] "Recommendation of the European Parliament and of the Council of 23 April 2008 on the establishment of the European Qualifications Framework for lifelong learning", Official Journal of the European Union, vol. 51, 2008/C 111/01

[4] J.C. Trinder, "Competency standards - A measure of the quality of a workforce", The International Archives of the Photogrammetry, Remote Sensing and Spatial Information Sciences, vol. 37, part B6a, Beijing 2008.
[5] E. Sabeil, A. A. Manaf, Z. Ismail, "Development of Malaysian digital forensics investigator competency identification methods", Advanced Machine Learning Technologies and Applications, Communications in Computer and Information Science, vol. 322, pp 554-565, 2012.

[6] Development of proposals for substantive and institutional implementation of the National Qualifications Framework and the National Qualification Register for learning throughout life, project undertaken by the Educational Research Institute, Warsaw 2010 - 2013 (in Polish).

[7] D. Kowalik, M. Kaczmarek, The national standard professional qualifications - Clothing Engineer, Ministry of Labour and Social Policy, Warsaw 2007.

[8] The improvement of basic curricula as a key to the modernisation of vocational education, project undertaken by the MEN - KOWEZiU, Warszawa 2008-13 (in Polish).

[9] Vocational school as a school of a positive choice, project undertaken by the MEN - KOWEZiU, Warszawa 2010-13, (in Polish).

[10] A basic curriculum for professions, Ministry of National of Education, Warsaw 2012 (in Polish).

[11] D. Kowalik, M. Kaczmarek, How to implement modular vocational curricula. A guide for clothing industry, MEN - KOWEZiU, Warsaw 2012.

[12] The development of the set of vocational competence standards required by employers. 9.2.2. The development of factual and institutional assumptions of the implementation of the National Qualification Framework and The National Repository of Qualifications for lifelong learning, project undertaken by the Ministry of Labour and Social Policy, Warszawa 2012-13 (in Polish)

[13] J. Pujol, Occupation Analysis: Application Manual for Vocational Training Institutions, CINTERFOR - ILO, Montevideo 1987

[14] The Polish Classification of Occupations and Specializations for Labour Market Needs, Ministry of Labour and Social Policy, Warsaw 2010 (in Polish).

[15] International Standard of Classification of Occupations (ISCO-08), complited by the International Labour Office, Geneva 2008.

[16] "Recommendation of the European Parliament and of the council of 18 December 2006 on key competences for lifelong learning", Official Journal of the European Union, vol. L 10, 2006 (2006/962/EC). 